Acta vet. scand. $1984,25,352-364$.

From the Department of Food Hygiene, College of Veterinary Medicine, Helsinki, Finland.

\title{
DETECTION OF CHLORAMPHENICOL RESIDUES IN PIGS WITH DIFFERENT AGAR DIFFUSION METHODS
}

\author{
By \\ Hannu Korkeala and Osmo Mäki-Petäys
}

\begin{abstract}
KORKEALA, H. and O. MÄKI-PETÄYS: Detection of chloramphenicol residues in pigs with different agar diffusion methods. Acta vet. scand. $1984,25,352-364$. - Various tissues and body fluids of pigs given chloramphenicol intramuscularly at a dose level of $20 \mathrm{mg} / \mathrm{kg} 1.5,2.5$ and $18 \mathrm{~h}$ before slaughter were examined for drug residues with different agar diffusion methods. Zones of inhibition were observed in bile, kidney, muscle, serum and urine samples $1.5 \mathrm{~h}$ after drug administration. After $19 \mathrm{~h}$, residues were found only in the urine. The treatment of the bile, kidney, serum and urine samples with $\beta$-glucuronidase lowered the detection threshold of the agar diffusion methods for chloramphenicol. In addition, $\beta$-glucuronidase can be used for the identification of chloramphenicol residues. Chloramphenicol yielded the greatest zones of inhibition in kidney medulla and especially in urine with and without $\beta$-glucuronidase. $18 \mathrm{~h}$ after drug administration residues were found with $\beta$-glucuronidase treatment only in these samples. Urine and kidney medulla proved the best samples in the residue analysis of chloramphenicol at meat inspection.
\end{abstract}

antibiotics; kidney; tissue residues; betaglucuronidase; urine; meat inspetion.

Chloramphenicol is used in the treatment of food-producing animals in many countries. Used on humans, it can cause toxic side effects in the form of blood dyscrasias such as erythropoietic depression and aplastic anemia (Dameshek 1960, Kleint et al. 1965, Rosenthal \& Blackman 1965, Suhrland \& Weisberger 1970, Carpenter 1975), encephalopathy (Levine et al. 1970), the potentially fatal dose-related "grey baby" syndrome (Weiss et al. 1960, Craft et al. 1974) and liver damage (Gjone \& Orning 1966). A zero tolerance level for chloramphenicol has therefore been proposed by the joint FAO/WHO expert committee on edible tissues (WHO 1969). Yunis \& Bloomberg (1964) have 
suggested that chloramphenicol produces two types of bone marrow toxicity. One type occurs during chloramphenicol treatment, is usually dose related, and is characterized by a normocellular bone marrow and anemia. The second type of toxicity has a later onset ( 2 weeks to 5 months), is not necessarily dose related, and is characterized by an aplastic bone marrow, pancytopenia, and a fatal outcome. Most cases of aplastic anemia associated with chloramphenicol have occurred after oral administration of the drug (Holt 1967, Gleckman 1975).

Microbiological agar diffusion methods are widely used for the detection of antimicrobial residues at meat inspection. Chloramphenicol, however, is excreted principally in the form of microbiologically inactive metabolic products (Glazko et al. 1949), and microbiological routine methods have therefore not been sufficiently sensitive to detect low levels of chloramphenicol residues in slaughtered animals (Schothorst 1969, Fabiansson et al. 1976, Nouws \& Ziv 1978, Korkeala et al. 1983).

Glazko et al. (1950) and Uesugi et al. (1974) have observed that the drug is excreted in urine or in bile mainly as a conjugate with glucuronic acid. The glucuronide is readily hydrolyzed with the enzyme $\beta$-glucuronidase, yielding unchanged chloramphenicol (Glazko et al. 1950). Lee et al. (1982) have reported that chloramphenicol reactivated by $\beta$-glucuronidase in the urine of cows can then be detected by biological methods.

It was of interest to investigate whether the use of $\beta$-glucuronidase improves the sensitivity and suitability of microbiological methods for the detection of chloramphenicol residues in slaughtered pigs. To find the most suitable samples for the residue analysis, various porcine tissues and body fluids were examined. The effect of storage at $+4^{\circ} \mathrm{C}$ and of the freezing of the samples on chloramphenicol residues detected by microbiological methods was also studied.

\section{Sampling}

\section{MATERIALS AND METHODS}

Fourteen pigs, weight $39 \pm 9 \mathrm{~kg}(\overline{\mathrm{x}} \pm \mathrm{s})$ were treated with chloramphenicol (Leucomycin ${ }^{\circledR}$, Bayer, Leverkusen, Federal Republic of Germany). The drug was administered intramuscularly at the accepted dose level of $20 \mathrm{mg} / \mathrm{kg}$. Nine pigs were slaughtered $1 \frac{1}{2} \mathrm{~h}, 2$ pigs $2 \frac{1}{2} \mathrm{~h}$ and 3 pigs $18 \mathrm{~h}$ after administra- 
tion. Immediately after slaughter Musculus adductor, the kidneys and the liver were removed and the bile, serum and urine were collected. A qualitative microbiological analysis was carried out after collection of the samples. A portion of the samples was then stored for $24 \mathrm{~h}$ at $+4^{\circ} \mathrm{C}$ and another portion was frozen $\left(-18^{\circ}\right.$ C). After storage the samples were analyzed as before, and in addition a quantitative microbiological analysis was performed on a part of the frozen samples. 27 urine samples from pigs not treated with chloramphenicol were also collected and analyzed by qualitative microbiological methods and 20 liver samples by the Micrococcus luteus method.

\section{Qualitative microbiological assay}

The agar diffusion technique described by Korkeala et al. (1983) was used, with Micrococcus luteus ATCC 9341 and Bacillus subtilis BGA as test organisms. M. luteus was seeded on Pen assay agar (Orion Diagnostica, Espoo, Finland) and B. subtilis was added to Test agar $\mathrm{pH} 6.0$ for the inhibitor test (E. Merck, Darmstadt, Federal Republic of Germany) with $(0.15 \mu \mathrm{g} /$ $\mathrm{ml}$ of agar medium) and without trimethoprim (Sigma Chemical Co., St. Louis, Mo., USA) and to Test agar $\mathrm{pH} 8.0$ for the inhibitor test (E. Merck) containing $0.06 \mu \mathrm{g}$ trimethoprim per $\mathrm{ml}$ of agar medium. To analyze the bile, serum and urine, $0.1 \mathrm{ml}$ of the body fluid was impregnated onto filter-paper discs (Schleicher \& Schüll, Dassel, Federal Republic of Germany, $\emptyset 12.7 \mathrm{~mm}$ ).

All the samples were studied with and without the addition of $\beta$-glucuronidase (Sigma Chemical Co.). $0.05 \mathrm{ml}$ of filter sterilized $\beta$-glucuronidase ( 5000 units $/ \mathrm{ml}$ ) was pipetted onto the samples before incubation.

The size of the inhibition zones was measures from the edge of the sample or disc to the edge of the inhibition zone. Both complete and partial zones of inhibition were included.

The difference of means of the samples were computed using Student's t-test by the Survo 76 system (Mustonen \& Mellin 1982).

\section{Quantitative microbiological assay}

B. subtilis BGA was used as the test organism and Test agar pH 6.0 for the inhibitor test as the agar medium. $20 \mathrm{ml}$ of agar was poured onto Petri dishes $(\varnothing 9 \mathrm{~cm})$. After solidification, holes 
( $9 \mathrm{~mm}$ ) were punched into the agar. Two drops of the same agar were pipetted onto the bottom of the holes. Frozen tissue samples were homogenized with distilled water $(1: 1)$. The holes were filled with $0.1 \mathrm{~g}$ of the homogenates, with $0.1 \mathrm{ml}$ of body fluid or with $0.1 \mathrm{ml}$ of standard chloramphenicol solution. Triplicate determinations were carried out with and without $\beta$-glucuronidase. $0.05 \mathrm{ml}$ of $\beta$-glucuronidase solution ( 5000 units $/ \mathrm{ml}$ ) was pipetted onto the samples before incubation. The plates were first incubated $1 \mathrm{~h}$ at $+20^{\circ} \mathrm{C}$ and then $20 \mathrm{~h}$ at $+30^{\circ} \mathrm{C}$. The diameters of the inhibition zones were measured after the incubation period.

To calculate the concentration of the drug, the standard curve was determined with chloramphenicol (Oy Tamro Ab, Helsinki, Finland). Chloramphenicol was dissolved in ethanol and further diluted in distilled water. Ten parellel determinations were carried out for each dilution of chloramphenicol. The exponential line model $\mathbf{Y}=\mathrm{A} \times \mathrm{X}^{\mathrm{B}}(\mathrm{Y}=$ inhibition zone diameter in $\mathrm{mm}$ and $\mathrm{X}=$ concentration of chloramphenicol) was used as described by Nouws \& Ziv (1976). Parameters A and B of the model were estimated by computer, using the Survo 76 editor system (Mustonen 1981). A was 8.87 (standard error 0.23 ), $\mathrm{B}=0.24$ standard error 0.01 ) and the square of the correlation coefficient 0.94 $(n=90)$. The detection limit of the assay procedure was $1.1 \mu \mathrm{g}$ of chloramphenicol/ml.

\section{RESULTS}

Without $\beta$-glucuronidase treatment of the samples, inhibition zones were observed in kidney medulla and urine $1.5 \mathrm{~h}$ after chloramphenicol administration (Table 1). When M. luteus was used as the test organism, zones of inhibition were also found in muscle, liver and serum samples. The liver samples of pigs not treated with chloromphenicol yielded also inhibition zones $(5.1 \pm 0.9, \bar{x} \pm s)$ as after chloramphenicol treatment.

Inhibition zones after $\beta$-glucuronidase treatment were significantly greater than without enzymatic treatment in the bile, kidney, serum and urine samples (Table 1). The enzyme had no effect on the size of the inhibition zones in muscle and liver tissues. With B. subtilis methods the drug residues were not detectable in muscle samples.

Chloramphenicol yielded the largest zones of inhibition in kidney medulla and especially in urine, with and without $\beta$ - 


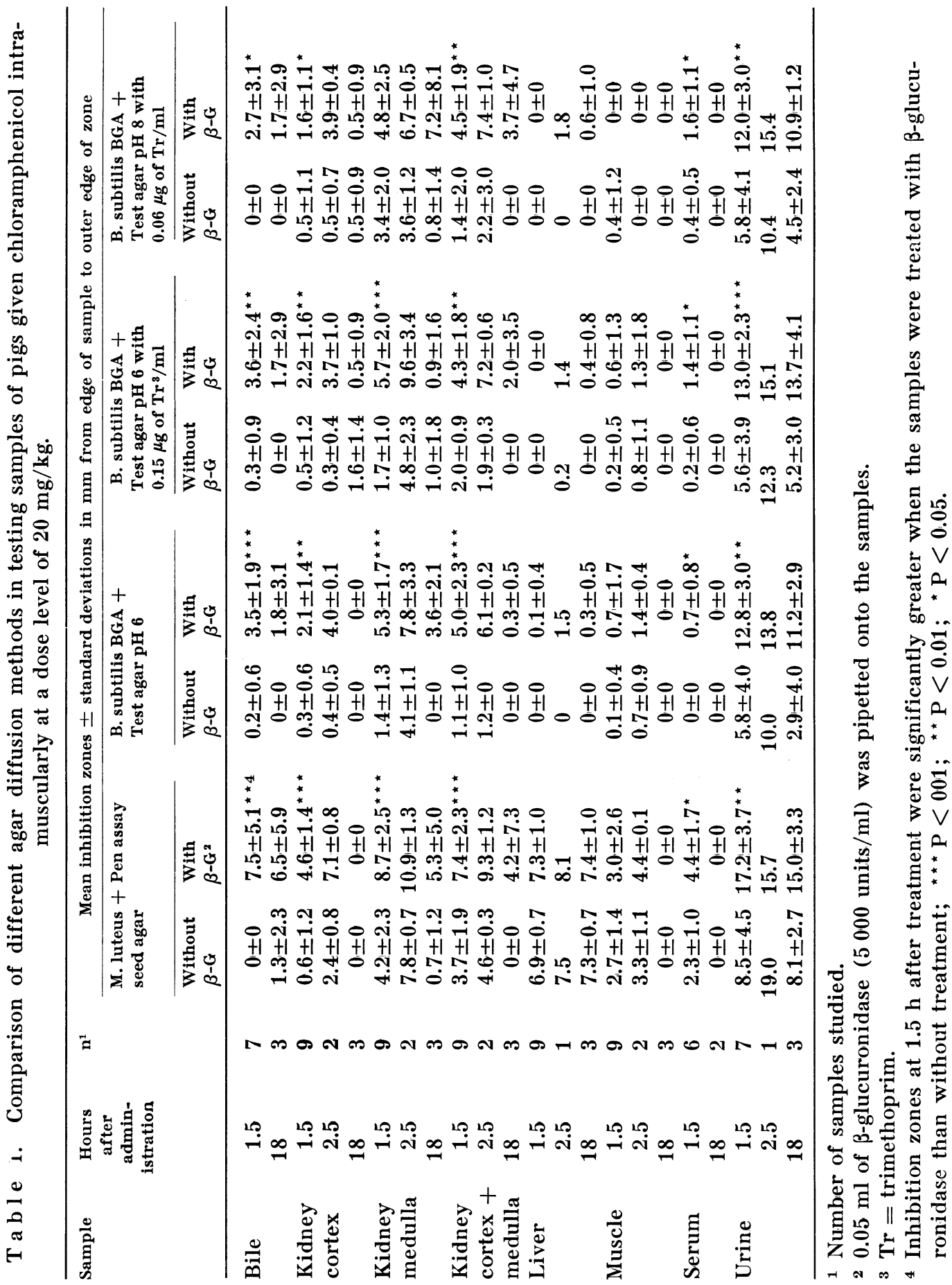


glucuronidase (Table 1). The zones of inhibition were noticeably larger in kidney medulla than kidney cortex, with different agar diffusion methods (Table 1). The urine of 27 pigs not treated with chloramphenicol yielded no zones of inhibition with any of the agar diffusion methods.

$18 \mathrm{~h}$ after drug administration, residues were observed only in urine with and without $\beta$-glucuronidase and in kidney medulla and bile with $\beta$-glucuronidase treatment (Table 1 ).

The results of the quantitative analysis are presented in Table 2. The chloramphenicol concentration was much higher in the urine than in the other samples.

Zones of inhibition were greater with M. luteus than with B. subtilis by agar diffusion methods (Table 1). With the former, however, the share of partial inhibition without a zone of complete inhibition was very marked, whereas with $B$. subtilis the zones of inhibition were more distinct.

$\mathrm{T}$ a b l e 2. Concentrations of drug residues $(\mu \mathrm{g} / \mathrm{ml}$ or $\mu \mathrm{g} / \mathrm{g})$ in tissues of pigs given chloramphenicol intramuscularly at a dose level of 20 $\mathrm{mg} / \mathrm{kg}$.

\begin{tabular}{lccclll}
\hline Sample & $\begin{array}{c}\text { Hours } \\
\text { after ad- } \\
\text { ministration }\end{array}$ & $\mathrm{n}^{1}$ & \multicolumn{2}{c}{ Without $\beta-\mathrm{G}$} & \multicolumn{2}{c}{ With $\beta-\mathrm{G}^{2}$} \\
\hline Bile & 1.5 & 5 & $\mathrm{ND}^{3}$ & & $\overline{\mathrm{x}}$ & range \\
& 18 & 2 & $\mathrm{ND}$ & & $\mathrm{ND}$ & \\
Kidney & 1.5 & 4 & 7.6 & $6.0-10.2$ & 19.7 & $7.2-47.0$ \\
cortex & 18 & 1 & 6.6 & & 27.4 & \\
Liver & 1.5 & 3 & 5.5 & $4.8-6.0$ & 9.1 & $5.2-16.4$ \\
& 18 & 2 & & ND-37.4 & & ND-22.0 \\
Muscle & 1.5 & 6 & & ND-6.4 & & ND-15.2 \\
& 18 & 2 & ND & & ND & \\
Serum & 1.5 & 6 & & ND-5.25 & & ND-15.5 \\
& 18 & 2 & ND & & ND & \\
Urine & 1.5 & 5 & 97.0 & $6.2-158.6$ & 356.3 & $110.9-496.8$ \\
& 18 & 1 & 9.2 & & 118.9 & \\
\hline
\end{tabular}

1 Number of the samples studied. Three parallel determinations were made from each sample.

${ }^{2} 0.05 \mathrm{ml}$ of $\beta$-glucuronidase ( 5000 units $/ \mathrm{ml}$ ) was pipetted onto the samples.

${ }^{3} \mathrm{ND}=$ not detected.

${ }^{4}$ Chloramphenicol was detected in 1 sample.

" Chloramphenicol was detected 3 samples. 


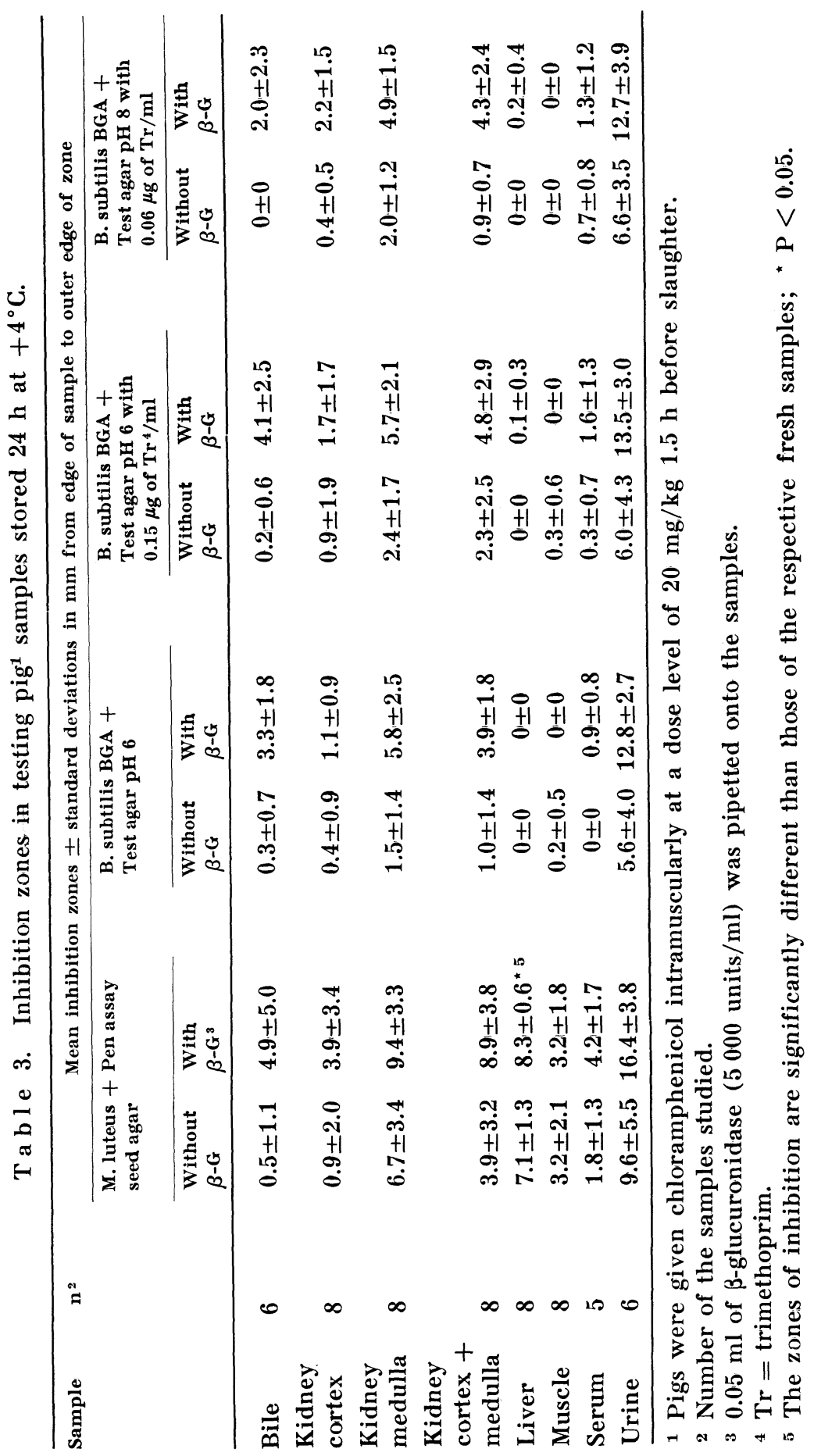




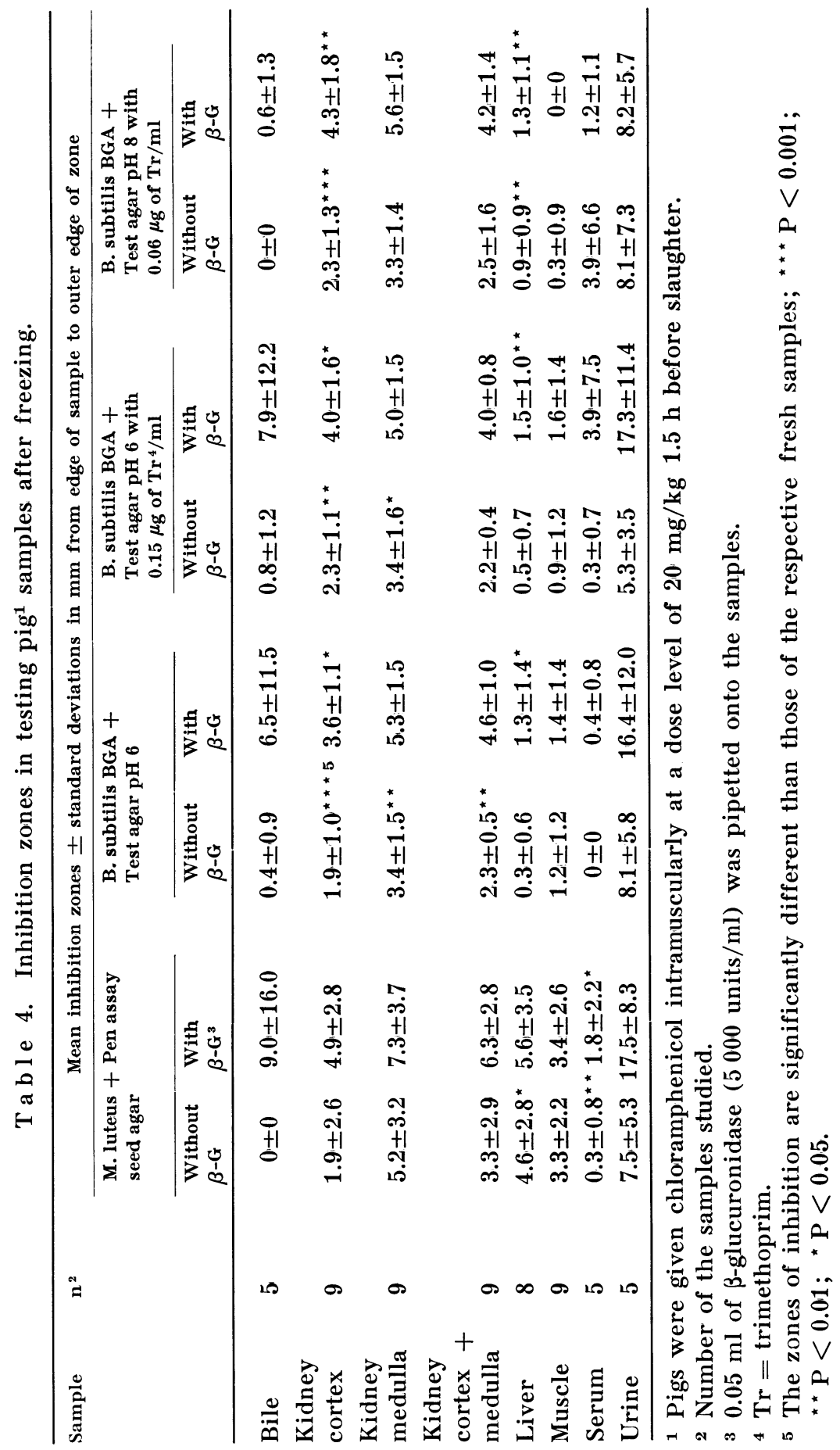


The size of the inhibition zones caused by chloramphenicol was not dependent on the $\mathrm{pH}$ of the agar medium.

The storage of the samples for $24 \mathrm{~h}$ at $+4^{\circ} \mathrm{C}$ had no effect on the zones of inhibition (Table 3 ). After freezing the zones of inhibition were larger in the kidney and liver samples but not in other samples (Table 4).

\section{DISCUSSION}

Chloramphenicol was concentrated in the kidney medulla and urine. Excretion of the drug as glucuronides by the renal route is also found in man and cattle (Glazko et al. 1949, Pilloud 1973, Nouws \& Ziv 1978). The compounds in the urine and kidneys of pigs were composed mainly of glucuronides, as shown by the effect of $\beta$-glucuronidase (Tables 1 and 2 ). It is therefore important to use the enzyme treatment in residue analysis at meat inspection. It is obvious that part of the chloramphenicol is excreted in pigs via the bile. However, the drug is apparently partly reabsorbed by the intestine into the blood circulation, as proposed by Sisodia et al. (1973), because of high concentration of chloramphenicol in urine. Urine and kidney medulla proved the best samples in residue analysis of chloramphenicol.

$18 \mathrm{~h}$ after drug administration, zones of inhibition were observed mainly in urine but also in kidney medulla and in bile. No chloramphenicol was found in meat (Tables 1 and 2).

When chloramphenicol is determined from the urine or kidney medulla, low chloramphenicol residues in meat can be indirectly observed. Nouws \& Ziv (1978) have calculated for cows that the time necessary to achieve a chloramphenicol level of 0.5 $\mu \mathrm{g} / \mathrm{ml}$ was $78 \mathrm{~h}$ for muscle drip and $165 \mathrm{~h}$ for the renal cortex. Their calculated withdrawal times for muscle drip and renal cortex at a level of $0.002 \mu \mathrm{g}$ chloramphenicol $/ \mathrm{ml}$ are 7.7 and 14.1 days, respectively. In addition, Narang et al. (1981) have observed that the half-life of chloramphenicol increased and the metabolic clearance rate decreased in patients with liver disease. The question merely arises whether these microbiological methods with $\beta$-glucuronidase, using kidney medulla or urine as samples, are sufficiently sensitive to ensure the acceptable level of chloramphenicol residues in meat.

The detection of smaller chloramphenicol residues was possible in kidney and urine samples when the samples were treated 
with $\beta$-glucuronidase, than without the treatment. In addition, $\beta$-glucuronidase can be used for the identification of chloramphenicol residues. The identification of antimicrobial residues is also an object of interest in microbiological residue studies ( $F a$ biansson et al. 1981, Korkeala et al. 1982, Haapoja \& Korkeala 1984). It is important to identify widely used and toxicologically significant drugs. Since nonspecific reactions are often observed with agar diffusion methods (Püschner \& Baur 1975, Korkeala et al. 1976, Heinert et al. 1976, Korkeala et al. 1982), the identification of the cause of the inhibition zone enhances the reliability of these methods at meat inspection. The test with $\beta$-glucuronidase is easy to carry out and thus also suitable for routine control at meat inspection.

Although M. luteus is more sensitive to chloramphenicol than B. subtilis (Table 1 ), a disadvantage of $M$. luteus is the poorer standardization of the method compared to the method using a B. subtilis spore suspension. In addition, the M. luteus method is difficult to interpret due to partial zones of inhibition caused for example by chloramphenicol. When $M$. luteus is used as the test organism, the identification of the cause of inhibition zone is most important.

Neither storage of the samples at $4^{\circ} \mathrm{C}$ nor freezing of the samples seems to have any apparent effect on the amount and activity of chloramphenicol in body tissues and fluids. The greater zones of inhibition observed after freezing of the kidney and liver samples than in the respective fresh samples are apparently due to tissue fluids released after the thawing of the frozen samples. These compounds can inhibit the growth of test bacteria.

\section{REFERENCES}

Carpenter, G.: Chloramphenicol eye-drops and marrow aplasia. Lancet $1975,2,326-327$.

Craft, A. W., J. T. Brocklebank, E. N. Hey \& R. H. Jackson: The "grey toddler" chloramphenicol toxicity. Archs. Dis. Childh. 1974, 49, 235-237.

Dameshek, W.: Chloramphenicol - a new warning. J. Amer. med. Ass. 1960, 174, 1853-1854.

Fabiansson, S., T. Nilsson \& J. Bäckström: Tissue concentrations of chloramphenicol after intramuscular injection in pigs. J. Sci. Fd. Agric. 1976, 27, 1156-1162. 
Fabiansson, S., C. Kihlberg, Å. Rutegård \& I. Anderson: Identifiering av kemoterapeutika i slaktkroppar. (Identification of antimicrobial drugs in slaughter animals. Svensk Vet.-Tidn. 1981, 33, 710.

Gjone, E. \& O. M. Orning: Jaundice due to chloramphenicol. Acta hepato-splenol. 1966, 13, 288-292.

Glazko, A. J., L. M. Wolf, W. A. Dill \& A. C. Bratton, Jr.: Biochemical studies on chloramphenicol (chloromycetin). II. Tissue distribution and excretion studies. J. Pharmac. exp. Ther. 1949, 96, $445-459$.

Glazko, A. J., W. A. Dill \& M. C. Rebstock: Biochemical studies on chloramphenicol (chloromycetin). III. Isolation and identification of metabolic products in urine. J. biol. Chem. 1950, 183, $679-691$.

Gleckman, R. A.: Warning - chloramphenicol may be good for your health. Archs. intern. Med. 1975, 135, 1125-1126.

Haapoja, A.\&H. Korkeala: Antimicrobial residues in milk. Comparison of different agar diffusion methods. Acta vet. scand. 1984, 25, $250-259$.

Heinert, H. H., G. van der Wall \& H. Brehmer: Lysozym - Ursache von unspezifischen Reaktionen im mikrobiologischen Hemmstofftest. (Lyzozyme - a cause of unspecific reaction in the microbiological assay for inhibitory substances). Arch. Lebensmittelhyg. 1976, 27, 55-60.

Holt, R.: The bacterial degradation of chloramphenicol. Lancet 1967, $1,1259-1260$.

Kleint, W., I. Oetzel \& I. Thümmel: Blutbildungsstörungen bei Chloramphenicolbehandlung im Kindesalter. (Disturbances in hematopoiesis in children treated with chloramphenicol). Pädiat. Grenzgeb. 1965, 4, 239-260.

Korkeala, H., R. Stabel-Taucher \& T. J. Pekkanen: The problem of testing horse kidneys for the presence of antibiotics at meat inspection: How to avoid a false positive reaction. Nord. Vet.Med. 1976, 28, 377-380.

Korkeala, H., O. Sorvettula, O. Mäki-Petäys \& J. Hirn: Comparison of different agar diffusion methods for the detection of antimicrobial residues in slaughter animals. Acta vet. scand. 1982, 23, 407 $-415$.

Korkeala, H., O. Sorvettula, O. Mäki-Petäys \& J. Hirn: Comparison of different agar diffusion methods for the detection of residues in the kidneys of pigs treated with antimicrobial drugs. Meat Sci. $1983,9,291-304$.

van der Lee, J. J., J. F. M. Nouws \& F. W. R. Bloemendal: Physicochemical methods for pharmacokinetic and residue analysis of chloramphenicol and degradation product in dairy cows. J. vet. Pharmacol. Ther. 1982, 5, 161-175.

Levine, P. H., W. Regelson \& J. F. Holland: Chloramphenicol - associated encephalopathy. Clin. Pharmacol. Ther. 1970, 11, 194199. 
Mustonen, S.: Survo 76 editor. Estimation of regression models. Research Report No. 29. Department of Statistics, University of Helsinki, Helsinki, Finland 1981.

Mustonen, S. \& I. Mellin: Survo 76 program descriptions. 2nd Ed., Department of Statistics, University of Helsinki, Finland 1982.

Narang, A. P. S., D. V. Datta, N. Nath \& V. S. Mathur: Pharmacokinetic study of chloramphenicol in patients with liver disease. Eur. J. clin. Pharmacol. 1981, 20, 479-483.

Nouws, J. F. M. \& G. Ziv: The effect of storage at $4^{\circ} \mathrm{C}$ on antibiotic residues in kidney and meat tissues of dairy cows. Tijdschr. Diergeneesk. 1976, 101, 1145-1153.

Nouws, J. F. M. \& G. Ziv: A study of chloramphenicol distribution and residues in dairy cows. Tijdschr. Diergeneesk. 1978, 103, $725-735$.

Pilloud, M.: Pharmacokinetics, plasma protein binding and dosage of chloramphenicol in cattle and horses. Res. Vet. Sci. 1973, 15, 231-238.

Püschner, J.\& E. Baur: Ein Beitrag zum Nachweis von Hemmstoffen in Schweinenieren. (A survey on the detection of inhibitory substances in the kidneys of slaughtered pigs). Schlachten und Vermarkten 1975, 75, 337-339.

Rosenthal, R. L. \& A. Blackman: Bone-marrow hypoplasia following use of chloramphenicol eye drops. J. Amer. med. Ass. 1965, 191, 136-137.

von Schothorst, M.: Residue van antibiotica in slachtdieren. (Antibiotic residues in slaughter animals). Diss., Utrecht, Holland, 1969.

Sisodia, C. S., R. H. Dunlop, V. S. Gupta \& L. Taksas: A pharmacologic study of chloramphenicol in cattle. Amer. J. vet. Res. 1973, 34, $1147-1151$.

Suhrland, L. G. \& A. S. Weisberger: Chloramphenicol toxicity in liver and renal disease. Archs. intern. Med. 1963, 112, 747-754.

Uesugi, T., M. Ikeda, Y. Kanel, R. Hori \& T. Arita: Studies on the biliary excretion mechanisms of drugs. II. Biliary excretion of thiamphenicol, chloramphenicol and their glucuronides in the rat. Biochem. Pharmac. 1974, 23, 2315-2321.

Weiss, C. F., A. J. Glazko \& J. K. Weston: Chloramphenicol in the newborn infant; a physiologic explanation of its toxicity when given in excessive doses. New Engl. J. Med. 1960, 262, 787-794.

WHO: Specifications for the identity and purity of food additives and their toxicological evaluation: Some antibiotics. Wld Hith Org. tech. Rep. Ser. No. 430, Geneva, Switzerland 1969.

Yunis, A. A. \& G. R. Bloomberg: Chloramphenicol toxicity: clinical features and pathogenesis. Prog. Hemat. 1964, 4, 138-159. 


\section{SAMMANFATTNING}

Undersökning av kloramfenikolrester hos gris med olika agardiffusionsmetoder.

Olika vävnader och kroppsvätskor hos gris, som hade givits kloramfenikol $(20 \mathrm{mg} / \mathrm{kg})$ intramuskulärt $1.5,2.5$ och $18 \mathrm{~h}$ före slakt, undersöktes med olika agardiffusionsmetoder för läkemedelsrester. Hämningszoner observerades i galla, njure, muskel samt serum prov $1.5 \mathrm{~h}$ efter administrationen. Rester kunde efter $18 \mathrm{~h}$ konstateras enbart från urinprov. Då gallan, njurarna, serumet och urinproven behandlades med $\beta$-glucuronidas, minskade den kloramfenikolnivå, som kunde iakttagas med agardiffusionsmetoden. Dessutom kan $\beta$-glucuronidas användas för identification av kloramfenikolrester. Njurmedulla och speciellt urin gav de största hämningszonerna med och utan tilskott av $\beta$-glucuronidas. $18 \mathrm{~h}$ efter medicin administrationen kunde rester iaktagas enbart ur dessa prov behandlades med $\beta$-glucuronidas. Urin och njurmedulla befanns vara de bästa proven för analys av kloramfenikolrester vid köttbesiktning.

(Received May 28, 1984).

Reprints may be requested from: Hannu Korkeala, the Department of Food Hygiene, College of Veterinary Medicine, P. O. Box 6, SF-00551 Helsinki 55, Finland. 